Bay (Eastern Adriatic coast). In: Haegal, F.H., Lewandowski, H., Urban, B.K. (Eds.), Horizonte 2000, 6. Wolfgang Ostwald Kolloqium der Kolloid-Gesellschaft Forschungszentrum Juelich, Band 9, 1998, p. 110.

Kwokal, Ž., Branica, M., 2000. Determination of dissolved monomethyl-mercury in saline, estuarine and freshwaters in Croatia. Croat. Chem. Acta 73, 97-109.

Kwokal, Ž., Branica, M., 2001. Occurrence of dimethylmercury in the polluted part of Kaštela Bay. Rapp. Comm. Int. Mer. Medit. 36, 141.

Martinčić, D., Kwokal, Ž., Stoeppler, M., Branica, M., 1989. Trace metals in sediments from the Adriatic Sea. Sci. Total Environ. 84, 135-147.

Mikac, N., Picer, M., Stegnar, P., Tušek-Žinidarić, M., 1985. Mercury distribution in a polluted marine area, ratio of total mercury, methylmercury and selenium in sediments, mussels and fish. Water Res. 19, 1387-1392.

Mikac, N., Niessen, S., Ouddane, B., Wartel, M., 1999. Speciation of mercury in sediments of the Seine estuary (France). Appl. Organomet. Chem. 13, 715-725.

Niessen, S., Foucher, D., Fischer, J.-C., Kwokal, Ž., Mikac, N., 2001. Mercury and sulphur speciation in contaminated coastal sediments (Kaštela bay, Croatia). RMZ-Mater. Geoenviron. 48 (1), 229234.
Odžak, N., Zvonarić, T., Horvat, M., 1996. Mercury distribution in the surface sediments of the Kaštela Bay. International Conference on Mercury as a Global Pollutant (Book of Abstracts), Hamburg, p. 493.

Pourbaix, M., 1963. Atlas of Electrochemical Equilibria. Pergamon Press, Oxford.

Rossbach, M., May, K., 1993. Mercury and methyl mercury determination using a modified CVVAAS system. Indokimia 1 (2), 15-20.

Stegnar, P., Vukadin, I., Smodis, B., Vakselj, A., Prosenc, A., 1980. Trace elements in sediments and organisms from Kaštela Bay. J. Etud. Pollut. CIESM 5, 595-600.

Watras, C.J., Bloom, N.S., Claas, S.A., Morrison, K.A., Gilmour, C.C., Craig, S.R., 1995. Methyl mercury production in the anoxic hypolimnion of a dimictic seepage lake. Water Air Soil Pollut. 80 (1-4), 735-745.

Zvonarić, T., Horvat, M., Stegnar, P., 1987. Ecological cycle of mercury in the marine environment of Kaštela Bay (Preliminary results). In: Papers Presented at the VI International Conference on Heavy Metals in the Environment, New Orleans, USA, vol. 2, pp. 461463.

Zvonarić, T., 1991. In: MAP Technical Reports Series No. 59. UNEP, Athens, pp. 369-381.

Zvonarić, T., 2001. Mercury contamination of the Kaštela Bay. RMZ-Mater. Geoenviron. 48 (1), 235-240.

0025-326X/02/\$ - see front matter @ 2002 Elsevier Science Ltd. All rights reserved.

PII: S0025-326X(02)00134-0

\title{
Determination of organohalogenated contaminants in liver of harbour porpoises (Phocoena phocoena) stranded on the Belgian North Sea coast
}

\author{
A. Covaci ${ }^{\mathrm{a}, *}, \mathrm{~K}$. Van de Vijver ${ }^{\mathrm{b}}$, W. DeCoen ${ }^{\mathrm{b}}, \mathrm{K}$. Das ${ }^{\mathrm{c}}$, J.M. Bouquegneau ${ }^{\mathrm{c}}$, \\ R. Blust ${ }^{\mathrm{b}}$, P. Schepens ${ }^{\mathrm{a}}$ \\ ${ }^{a}$ Toxicological Center, University of Antwerp, Universiteitsplein 1, 2610 Wilrijk, Belgium \\ ${ }^{\mathrm{b}}$ Department of Biology, University of Antwerp, Groenenborgerlaan 171, 2020 Antwerpen, Belgium \\ ${ }^{\mathrm{c}}$ Department of Oceanography, University of Liege, 4000 Sart Tilman, Belgium
}

Keywords: Polychlorobiphenyls; Polybrominated diphenyl ethers; Organochlorine pesticides; Harbour porpoises; North Sea

The harbour porpoise (Phocoena phocoena) is one of the smallest cetaceans in the world. Their diet is varied and consists mainly of herring (Clupea harengus), mackerel (Scomber scombrus), sprat (Sprattus sprattus) and whiting (Merlangius merlangius). Daily, they eat an equivalent of $4-9.5 \%$ of their total body weight. Seasonal migrations can occur and their trajectory follows the availability of food supply. In summer, they stay in coastal waters (not deeper than $150 \mathrm{~m}$ ), while in winter

\footnotetext{
${ }^{*}$ Corresponding author. Tel.: +32-3-820-2704; fax: +32-3-820-2722.

E-mail address: covaci@uia.ua.ac.be (A. Covaci).
}

they move to open waters, together with a north-south migration. Thus, they might be considered indicators of coastal pollution and high concentrations of anthropogenic contaminants in the organism are expected from animals living in polluted seas, such as the North or Baltic Seas (Kleivane et al., 1995; van Scheppingen et al., 1996; Bruhn et al., 1999). The harbour porpoise is listed as a vulnerable species in European waters. During recent decades the number of observations of harbour porpoise has drastically decreased, especially in the Baltic and North Sea. One of the main threats to the harbour porpoise is accidental capture by fishing gear. High levels of contaminants, declining fish stocks and 
other anthropogenic stress factors are also considered potential threats. Organohalogen contaminants (such as PCBs and DDTs) have been found at levels that may present risk to cetaceans (Aguilar and Borrell, 1994; Jepson et al., 1999). The relationship between organochlorines and reproductive, endocrine and immunological disorders has also been strongly suspected (Jepson et al., 1999) in marine mammals from highly contaminated areas (De Guise et al., 1995). The capacity to metabolise PCBs and DDTs is known to be low in small cetaceans compared to birds and terrestrial mammals (Boon et al., 1997; Tanabe et al., 1988). Thus, the less efficient metabolism of DDTs and ortho-substituted PCBs in cetaceans compared to seals and terrestrial mammals could also lead to greater biomagnification and possible adverse effects. Compared to the well-documented occurrence of organochlorine contaminants, only few studies have been performed concerning the environmental exposure assessment towards other persistent organohalogen compounds such as polybrominated diphenyl ethers (PBDEs). These chemicals can be considered as an important class of chemicals, which are highly lipophilic and show low biodegradation capacity. They belong to the group of brominated flame retardants and their applications range from plastics, textiles, furniture to construction materials and electronics (Darnerud et al., 2001). Some of these compounds have been detected in abiotic compartments of the aquatic ecosystem (e.g. sediments and sewage sludge). Moreover, they tend to accumulate in the aquatic food chain, including the North Sea ecosystem (Zegers et al., 2001). These reports indicate that PBDEs have been detected in top predators like seals and whales, showing that these contaminants have already reached the deep-sea ecosystems (de Boer et al., 1998). This study aims to evaluate the occurrence and trends of important organic contaminants, such as organochlorine pesticides, PCBs and PBDEs, in harbour porpoise, a representative top predator for the North Sea ecosystem.

Liver samples were obtained from 21 harbour porpoises stranded at the Belgian North Sea coast between 1997 and 2000 and were kept at $-20{ }^{\circ} \mathrm{C}$ until analysis. All samples were cut out from the middle of the tissue sample to avoid possible contamination from handling and storage. Life-history data for the porpoises are presented in Table 1. No information about the health condition of the animal at the time of stranding was available. The samples were analysed for 74 mono- and multi-ortho PCB congeners, $\mathrm{HCH}$ isomers $(\alpha-, \beta-$, and $\gamma-), \mathrm{HCB}$, DDT and metabolites (6 $o p$ - and $p p$-isomers) and for eight PBDE congeners (IUPAC no. 28, 47, 66, 71, 99, 100, 153 and 154). CB 46, CB 143, $\varepsilon-\mathrm{HCH}$ and ${ }^{13} \mathrm{C}$-BDE 47, 99 and 153 were used as internal standards. The method was previously described in Covaci et al. (2002) and Jacobs et al. (in press). Briefly, $5 \mathrm{~g}$ liver were ground with $20 \mathrm{~g}$ anhydrous sodium sulphate and, after the addition of internal standards, the obtained fine floating powder was extracted using an accelerated Soxhlet extractor with $60 \mathrm{ml}$ hexane:methylene chloride:acetone $(3: 1: 1, \mathrm{v} / \mathrm{v})$ for $2 \mathrm{~h}$. The extract was concentrated, transferred to a pre-weighed tube and completely dried under a gentle nitrogen stream and then kept at $60{ }^{\circ} \mathrm{C}$ until constant mass. The measured

Table 1

Life-history data for the harbour porpoises stranded on the Belgian North Sea Coast (1997-2000)

\begin{tabular}{|c|c|c|c|c|c|c|c|c|}
\hline Liver & Stranding year & Amount (g) & Fat $(\%)$ & Age & Sex & Length $(\mathrm{cm})$ & Weight (kg) & Blubber thickness $(\mathrm{mm})$ \\
\hline 1 & 1997 & 24.42 & 1.63 & $\bar{j}$ & $\mathrm{M}$ & 108 & 21 & 11 \\
\hline 2 & 1997 & 2.27 & 3.28 & $\mathrm{j}$ & $\mathrm{F}$ & 125 & 39 & 35 \\
\hline 3 & 1997 & 4.57 & 3.94 & $\mathrm{j}$ & $\mathrm{F}$ & 118 & 28 & 25 \\
\hline 4 & 1997 & 2.22 & 3.63 & $\mathrm{j}$ & M & 118 & 22 & 10 \\
\hline 5 & 1997 & 4.28 & 4.06 & $\mathrm{a}$ & M & 151 & 39 & 11 \\
\hline 6 & 1998 & 4.7 & 9.17 & $\mathrm{a}$ & M & 144 & 33 & 13 \\
\hline 7 & 1999 & 2.92 & 6.15 & $\mathrm{a}$ & $\mathrm{F}$ & 134 & 30 & 15 \\
\hline 8 & 1999 & 4.55 & 1.57 & $\mathrm{j}$ & $\mathrm{F}$ & 116 & 17 & 8 \\
\hline 9 & 1999 & 4.56 & 3.79 & $\mathrm{j}$ & M & 106 & 17 & 4 \\
\hline 10 & 1999 & 3.95 & 7.12 & $\mathrm{j}$ & M & 103 & 16 & 8 \\
\hline 11 & 1999 & 3.96 & 3.08 & $\mathrm{j}$ & M & 108 & 15 & 8 \\
\hline 12 & 1999 & 3.99 & 21.74 & $\mathrm{j}$ & M & 80 & 7 & 6 \\
\hline 13 & 2000 & 4.05 & 10.75 & $\mathrm{j}$ & M & 99 & 16 & 8 \\
\hline 14 & 2000 & 21.45 & 6.42 & $\mathrm{j}$ & $\mathrm{M}$ & 108 & 18 & 10 \\
\hline 15 & 2000 & 4.47 & 7.48 & $\mathrm{a}$ & M & 142 & 41 & 10 \\
\hline 16 & 2000 & 4.38 & 3.92 & $\mathrm{a}$ & $\mathrm{F}$ & 151 & 42 & 10 \\
\hline 17 & 2000 & 4.02 & 6.74 & $\mathrm{a}$ & M & 144 & 43 & 14 \\
\hline 18 & 2000 & 3.58 & 3.41 & $\mathrm{a}$ & M & 149 & 37 & 8 \\
\hline 19 & 2000 & 4.39 & 11.96 & $\mathrm{j}$ & M & 103 & 27 & 8 \\
\hline 20 & 2000 & 4.44 & 15.78 & $\mathrm{j}$ & $\mathrm{F}$ & 114 & 22 & 20 \\
\hline 21 & 2000 & 3.87 & 3.24 & $\mathrm{a}$ & M & 150 & 39 & 9 \\
\hline
\end{tabular}

$\mathrm{j}-\mathrm{Juvenile}$ if age $<2 \mathrm{yr}$; a-adult if age $>2 \mathrm{yr}$; $\mathrm{F}$-female; $\mathrm{M}-$ male. 
weight represented the fat content of the sample. The fat extract was solubilised in hexane and was applied to a hexane pre-washed SPE cartridge filled (from the bottom to top) with $2 \mathrm{~g}$ deactivated alumina and $5 \mathrm{~g}$ acid silica. $30 \mathrm{ml}$ of hexane were used for complete elution of all POPs. The final eluate was concentrated under nitrogen to approximately $200 \mu \mathrm{l}$.

All organochlorine analyses were performed on a Hewlett Packard (HP) 6890/5973 gas chromatographmass spectrometer connected to a $50 \mathrm{~m} \times 0.22 \mathrm{~mm} \times$ $0.25 \mu \mathrm{m}$, HT-8 (SGE) capillary column. The mass spectrometer was operated in electron impact ionisation mode. Three most abundant ions were monitored for each level of chlorination for PCBs or for each pesticide. Method limits of detection for individual PCB congeners ranged between 0.5 and $2 \mathrm{ng} / \mathrm{g}$ lipid. For HCHs and DDTs, the detection limit was $2 \mathrm{ng} / \mathrm{g}$ lipid for each isomer. Recoveries of target compounds ranged between $72 \%$ and $80 \%$.

The PBDE analysis, previously described in Covaci et al. (in press) was performed on a GC-MS equipped with a $10 \mathrm{~m} \times 0.10 \mathrm{~mm} \times 0.10 \mu \mathrm{m}$ AT-5 (Alltech) capillary column. Helium was used as carrier gas at constant flow $(0.4 \mathrm{ml} / \mathrm{min})$. Two most abundant ions $\left(\mathrm{M}^{+}\right.$ and $[\mathrm{M}+2]^{+}$for the tri-, tetra-, and penta-congeners and $[\mathrm{M}-2 \mathrm{Br}]^{+}$and $[\mathrm{M}-2 \mathrm{Br}+2]^{+}$for the hexacongeners) were monitored for each level of bromination for native and labelled BDEs. Recoveries of internal standards, ${ }^{13} \mathrm{C}$-labeled BDEs ranged between $81 \%$ and $103 \%$ with a standard deviation of $<21 \%$. Method limits of detection for individual BDE congeners ranged between 0.5 and $2 \mathrm{ng} / \mathrm{g}$ lipid.

Means were calculated using half of the limit of detection for not detected values. Retention times, ion chromatograms and intensity ratios of the monitored ions were used as identification criteria. A deviation of the ion intensity ratios within $20 \%$ of the mean values of the calibration standards was considered acceptable. The method performance was assessed through rigorous quality control, which included daily check of calibration curves, regular analysis of procedural blanks and certified material CRM 350 (PCBs in mackerel oil) and participation in interlaboratory tests for $\mathrm{PCBs}$ and PBDEs.

The most abundant organochlorine pesticides were DDT and its metabolites, followed by HCB and HCHs (Table 2). Dieldrin, reported to be an important contaminant in cetaceans, was not measured in this study, due to its degradation during the clean-up on acidified silicagel. Two porpoise samples contained extreme values of DDTs (16.8 and $44.3 \mu \mathrm{g} / \mathrm{g}$ lipid, respectively) and they were not included in the calculations of means. $\mathrm{HCB}$ and $\mathrm{HCH}$ concentrations were relatively low, and $\gamma-\mathrm{HCH}$ was the most abundant $\mathrm{HCH}$ isomer with an average contribution of $96 \%$ to the total $\mathrm{HCH}$ concentration (range $71-100 \%$ ). The $\alpha-$ and $\beta-\mathrm{HCH}$ isomers were detected only in 5 and 3 samples, respectively, out of 21. PCBs were the most important organochlorine contaminants in the harbour porpoises (Table 2). Two samples had more than $100 \mu \mathrm{g} / \mathrm{g}$ lipid for the sum of 59 congeners (359 and $404 \mu \mathrm{g} / \mathrm{g}$ lipid) and they were excluded from further calculations. These abnormal high values are probably not due to the analytical procedure since other parameters, such as PBDEs, HCHs, HCB and percentage lipid, were all within the range observed in the other 19 samples. For the remaining 19 samples, the mean concentration for 59 congeners was $36.4 \pm 26.4 \mu \mathrm{g} / \mathrm{g}$ lipid (Table 2). To enable comparison with other studies, the mean of seven $\mathrm{CB}$ congeners (IUPAC no. 28, 52, 101, 118, 138, 153 and 180) proposed by the International Council for the Exploration of the Sea (ICES) was calculated and found to be $17.8 \pm 13.7 \mu \mathrm{g} / \mathrm{g}$ lipid (range $0.8-198.4 \mu \mathrm{g} / \mathrm{g}$ lipid). The seven ICES CBs constituted on average $48 \%$ of the sum of $\mathrm{CB}$ congeners. Similar with that found in another study (Karlson et al., 2000), the major contributing PCB congeners were $153(24 \%)$, followed by $138(13 \%), 149$ (8.1\%), 187 (7.4\%), $180(6.8 \%)$ and $99(4.2 \%)$. The mean concentration of CB 153 was $8.5 \pm 7.1$, while the median was $7.0 \mu \mathrm{g} / \mathrm{g}$ lipid. Furthermore, similar to previous observations (Karlson et al., 2000), the hexa-CB congeners dominated the profile $(58 \%)$, followed by heptaCBs $(26 \%)$ and penta-CBs (11\%). PBDEs were found in relatively high concentrations. The mean concentration for the sum of eight congeners was $2.3 \pm 1.8 \mu \mathrm{g} / \mathrm{g}$ lipid, ranging from 0.4 to $5.8 \mu \mathrm{g} / \mathrm{g}$ lipid (Table 2). In contrast with $\mathrm{CB}$ values, there were no extremely high values for PBDEs and the range was relatively small (one order of magnitude). As found in other studies (Law and Allchin, 2001; Zegers et al., 2001), the principal contributor was BDE 47 with a mean concentration of $1.1 \pm$ $0.9 \mu \mathrm{g} / \mathrm{g}$ lipid. Other important PBDE congeners routinely detected in marine biota were BDE 99, 100, 154 and 153.

Median concentrations of PCBs, DDTs and PBDEs were higher in the adult group $(n=8)$ than in the juveniles $(n=13)$ (Fig. 1(a)). For HCB and HCHs, no difference was observed between the age groups. Concentrations of PCBs, DDTs, PBDEs and HCB were significantly higher in males $(n=15)$ than in females $(n=6)$, probably due to a loss of PCB load of females through gestation and lactation (Fig. 1(b)). Furthermore it can be seen that the increase in PCB body burden for males with age is faster than for females (Fig. 2). It was suggested in other studies (van Scheppingen et al., 1996) that in harbour porpoises, the TCDD-equivalent (TEQ) toxicity of PCBs is more important than the PCDD/ PCDF TEQ toxicity. The TEQ values of mono-ortho PCBs (MO-PCBs) calculated in Table 3 were similar with values obtained from specimens caught in the Black Sea (Tanabe et al., 1997) or Mediterranean Sea (Jimenez et al., 2001). 
Table 2

Mean, standard deviation, median and range of concentrations for the organohalogenated contaminants measured in the liver of 21 harbour porpoises stranded at the Belgian North Sea coast

\begin{tabular}{|c|c|c|c|c|}
\hline Compounds & No. of samples & Mean $^{*} \pm \mathrm{SD}(\mu \mathrm{g} / \mathrm{g}$ lipid $)$ & Median ( $\mu \mathrm{g} / \mathrm{g}$ lipid $)$ & Range ( $\mu \mathrm{g} / \mathrm{g}$ lipid) \\
\hline $\mathrm{HCB}$ & 21 & $0.7 \pm 0.4$ & 0.6 & $0.1-5.7$ \\
\hline$\alpha-\mathrm{HCH}$ & 21 & $0.1 \pm 0.1$ & nd & nd -0.1 \\
\hline$\beta-\mathrm{HCH}$ & 21 & $0.1 \pm 0.1$ & nd & nd- -0.2 \\
\hline$\gamma-\mathrm{HCH}$ & 21 & $0.2 \pm 0.1$ & 0.2 & $0.1-1.9$ \\
\hline$\Sigma \mathrm{HCHs}$ & 21 & $0.2 \pm 0.2$ & 0.2 & $0.1-2.3$ \\
\hline$\gamma-\mathrm{HCH} / \Sigma \mathrm{HCHs}$ & 21 & $0.96 \pm 0.08$ & 1.00 & $0.71-1.00$ \\
\hline$p, p^{\prime}$-DDE & 21 & $2.3 \pm 1.5$ & 1.9 & $0.2-24.4$ \\
\hline$o, p^{\prime}$-DDD & 21 & $0.2 \pm 0.2$ & 0.1 & nd-2.7 \\
\hline$p, p^{\prime}$-DDD & 21 & $0.8 \pm 0.6$ & 0.6 & $0.1-14.6$ \\
\hline$o, p^{\prime}$-DDT & 21 & $0.1 \pm 0.2$ & 0.1 & nd -0.9 \\
\hline$p, p^{\prime}$-DDT & 21 & $0.2 \pm 0.3$ & 0.1 & nd-1.9 \\
\hline$\Sigma$ DDTs & 21 & $3.4 \pm 2.3$ & 2.6 & $0.3-44.3$ \\
\hline$p, p^{\prime}-\mathrm{DDE} / \Sigma \mathrm{DDTs}$ & 21 & $0.69 \pm 0.06$ & 0.70 & $0.55-0.77$ \\
\hline CB 153 & 21 & $8.5 \pm 7.1$ & 7.1 & $0.3-98.8$ \\
\hline Tri-CB & 21 & $0.1 \pm 0.1$ & 0.1 & nd -0.4 \\
\hline Tetra-CB & 21 & $1.0 \pm 0.6$ & 0.9 & $0.2-16.5$ \\
\hline Penta-CB & 21 & $4.0 \pm 2.6$ & 3.8 & $0.5-37.1$ \\
\hline Hexa-CB & 21 & $20.7 \pm 15.4$ & 18.4 & $0.9-241.6$ \\
\hline Hepta-CB & 21 & $9.2 \pm 7.5$ & 7.4 & $0.3-99.5$ \\
\hline Octa-CB & 21 & $1.2 \pm 1.2$ & 1.0 & nd-8.6 \\
\hline Nona-CB & 21 & $0.2 \pm 0.2$ & 0.1 & nd -0.8 \\
\hline Deca-CB & 21 & $0.1 \pm 0.1$ & 0.1 & nd -0.3 \\
\hline Sum PCBs (74 congeners) & 21 & $36.4 \pm 26.4$ & 33.8 & $1.9-404.5$ \\
\hline Sum 7 ICES PCBs ${ }^{* *}$ & 21 & $17.8 \pm 13.7$ & 15.2 & $0.8-198.4$ \\
\hline BDE 28 & 20 & $0.01 \pm 0.01$ & 0.01 & $\mathrm{nd}-0.25$ \\
\hline BDE 47 & 20 & $1.06 \pm 0.86$ & 0.90 & $0.19-2.83$ \\
\hline BDE 66 & 20 & $0.01 \pm 0.01$ & nd & nd- -0.04 \\
\hline BDE 71 & 20 & $0.05 \pm 0.05$ & 0.03 & $\mathrm{nd}-0.21$ \\
\hline BDE 99 & 20 & $0.35 \pm 0.32$ & 0.27 & $0.03-0.99$ \\
\hline BDE 100 & 20 & $0.36 \pm 0.32$ & 0.26 & $0.05-0.96$ \\
\hline BDE 153 & 20 & $0.20 \pm 0.17$ & 0.16 & nd -0.58 \\
\hline BDE 154 & 20 & $0.24 \pm 0.21$ & 0.17 & nd- -0.61 \\
\hline Sum BDEs (eight congeners) & 20 & $2.29 \pm 1.79$ & 2.18 & $0.41-5.81$ \\
\hline
\end{tabular}

nd-Not detected; *-two extremely high for DDTs and PCBs were not included; **-IUPAC no. 28, 52, 101, 118, 153, $138,180$.

The liver of harbour porpoises contains a wide variety of organohalogenated contaminants, as would be expected in a coastal ichthyophagous odontocete. Contemporary contaminant levels in other harbour porpoises populations have been mainly reported for PCBs and DDTs. As previously shown (Berggren et al., 1999), $p, p^{\prime}$-DDE was the main contributor to the total DDT. Concentrations of $p, p^{\prime}$-DDT and total DDT were relatively low, lower than those reported from North Sea (Granby and Kinze, 1991) or Baltic Sea porpoises (Bruhn et al., 1999). This is in accordance with the continuous decline in DDT concentrations in biota observed after the ban in the 1970s. The $p, p^{\prime}$-DDE/sum DDTs ratio is similar with the ratio found by Bruhn et al. (1999) in specimens from North Sea, but higher than the ratio observed in samples from the Arctic. One explanation might be that marine mammals and fish have induced levels of the cytochrome P450-1A and $2 \mathrm{~B}$ enzymes capable of metabolising $p, p^{\prime}$-DDT (Boon et al.,
1997). Higher values of the ratio indicate old input of DDT to the environment.

Concentrations of $\mathrm{HCHs}$ showed a similar trend with lower values for the most important isomer $(\gamma-\mathrm{HCH})$, while the sum of $\mathrm{HCHs}$ is comparable with previous studies from North Sea (Bruhn et al., 1999) and Baltic Sea porpoises (Berggren et al., 1999). The $\alpha$ - and $\beta-\mathrm{HCH}$ isomers were found to have a low contribution to the sum of HCHs for specimens caught in the North Sea. However, in Arctic animals (Bruhn et al., 1999), higher concentrations of $\alpha-\mathrm{HCH}$ were measured. This might be due to atmospheric long-range transport and to the photochemical isomerisation of $\gamma$ - to $\alpha-\mathrm{HCH}$.

PCB concentrations found in the porpoises stranded on the Belgian North Sea coast are also in agreement with concentrations reported in literature. The mean value for the sum of the seven ICES PCB congeners $(17.8 \mu \mathrm{g} / \mathrm{g}$ lipid) was similar to mean values found in samples from the Baltic (mean ranging from 11 to 

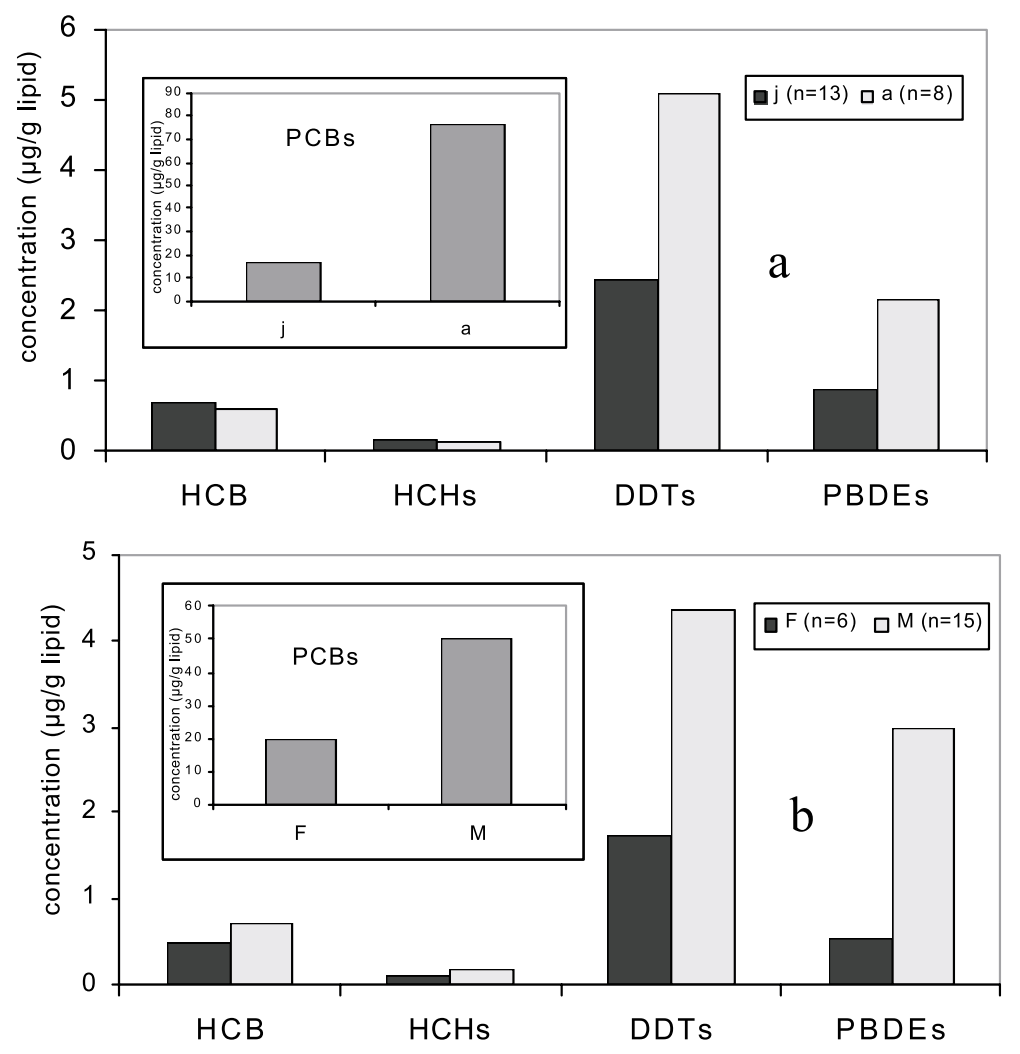

Fig. 1. Distribution of median concentrations of PCBs, HCB, HCHs, DDTs and PBDEs with age (a) and sex (b).

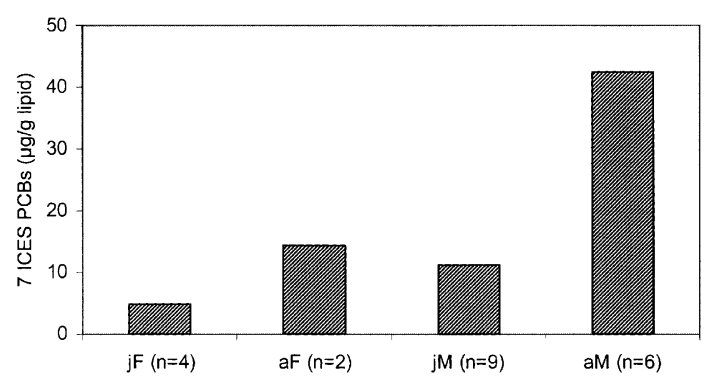

Fig. 2. Distribution of median concentrations of the seven ICES PCBs in harbour porpoises in function to their age and sex (jf-juvenile/ female, af — adult/female, jm—juvenile/male, am—adult/male).

$46 \mu \mathrm{g} / \mathrm{g}$ fat, function of location and year) (Berggren et al., 1999). Moreover, these concentrations compare favourably with concentrations measured in harbour porpoises captured on the English and Dutch coast of the North Sea or on the Welsh Atlantic coast (Table 4) (Law et al., 2002) or with porpoises caught in waters throughout the world.

Higher concentrations of organochlorine compounds were found in porpoises stranded on the Belgian/Dutch coast of the North Sea in comparison with the English coast (Table 4). There are good reasons why this might be, for instance the discharges from the Rhine, Meuse
Table 3

TEQ values (pg TEQ/g lipid) for mono-ortho $\mathrm{PCBs}$ in 21 porpoise livers

\begin{tabular}{llrrcc}
\hline CB & TEF & \multicolumn{1}{c}{$\begin{array}{l}\text { jm } \\
(n=9)\end{array}$} & $\begin{array}{c}\text { am } \\
(n=6)\end{array}$ & $\begin{array}{l}\text { jf } \\
(n=4)\end{array}$ & $\begin{array}{c}\text { af } \\
(n=2)\end{array}$ \\
\hline 105 & 0.0001 & 18.7 & 9.9 & 13.6 & 12.6 \\
114 & 0.0005 & 14.7 & 12.3 & 8.0 & 2.4 \\
123 & 0.0005 & 1.1 & 1.1 & 0 & 0 \\
118 & 0.0001 & 100.6 & 72.8 & 78.1 & 70.5 \\
156 & 0.0005 & 23.6 & 14.7 & 19.6 & 20.3 \\
157 & 0.00001 & 3.9 & 0.0 & 0 & 0 \\
167 & 0.0005 & 0.8 & 0.6 & 0.7 & 0.5 \\
189 & 0.0001 & 2.6 & 3.6 & 2.4 & 4.0 \\
Total & & 166.0 & 115.0 & 122.4 & 110.3 \\
MO-PCBs & & & & & \\
\hline
\end{tabular}

and Scheldt estuaries or the coastal currents from the French to the Dutch coast. Not too long ago, harbour porpoises from the Dutch coast of the North Sea (Smeenk, 1987) and seals (Ries et al., 1999) had high enough PCB levels to compromise their reproductive capacity. A concentration gradient for organochlorine pollutants is expected for the North Sea, with the highest values in the Southern part. This hypothesis is in accordance with the data presented in Table 4, as the porpoises stranded on the Belgian coast have higher 
Table 4

Values of the seven ICES CBs ( $\mu \mathrm{g} / \mathrm{g}$ lipid) in harbour porpoises collected in different locations from Scotland, Wales, England, the Netherlands (Law et al., 2002) and Belgium (this study)

\begin{tabular}{lrrcc}
\hline Location & Sex & $n$ & \multicolumn{2}{c}{ ICES 7 CBs $(\mu \mathrm{g} / \mathrm{g}$ lipid $)$} \\
\cline { 3 - 5 } & & & Mean \pm SD & Range \\
\hline Moray Firth & $\mathrm{F}$ & 10 & $2.2 \pm 1.5$ & $1.0-5.3$ \\
Cardigan Bay & $\mathrm{F}$ & 11 & $9.4 \pm 7.1$ & $2.9-23.5$ \\
E coast of England & $\mathrm{F}$ & 21 & $11.0 \pm 6.8$ & $0.2-22.1$ \\
Netherlands & $\mathrm{F}$ & 12 & $13.4 \pm 8.3$ & $2.6-26.5$ \\
Belgium (this study) & $\mathrm{F}$ & 6 & $9.5 \pm 9.1$ & $0.8-18.8$ \\
Moray Firth & $\mathrm{M}$ & 11 & $6.3 \pm 4.7$ & $1.0-16.7$ \\
Cardigan Bay & $\mathrm{M}$ & 10 & $22.3 \pm 18.7$ & $0.3-64.8$ \\
E coast of England & $\mathrm{M}$ & 35 & $14.1 \pm 12.4$ & $2.8-50.9$ \\
Netherlands & $\mathrm{M}$ & 10 & $24.7 \pm 13.4$ & $9.1-43.6$ \\
Denmark & $\mathrm{M}$ & 12 & $12.7 \pm 9.7$ & $5.5-37.6$ \\
Norway & $\mathrm{M}$ & 22 & $10.5 \pm 6.3$ & $2.0-23.7$ \\
Belgium (this study) & $\mathrm{M}$ & 15 & $19.0 \pm 23.1$ & $4.0-58.4$ \\
\hline
\end{tabular}

PCB concentrations than the Danish porpoises. High concentrations of PCBs have been measured in blubber of porpoises from the North Sea (47-160 $\mu \mathrm{g} / \mathrm{g}$ lipid) (Duinker et al., 1989). de Yanés and Buthe (1998) found relatively high concentrations of PCBs (sum of 51 congeners) in young (median: $31.6 \mu \mathrm{g} / \mathrm{g}$ lipid, range: $5.7-$ 180.3), female $(64.7 \mu \mathrm{g} / \mathrm{g}$ lipid, range 5.7-192.6) and male $(139.6 \mu \mathrm{g} / \mathrm{g}$ lipid, range 68.7-247.1) seals from the North Sea. Moreover, in comparison with porpoise populations from Iceland, the North Sea group contained much higher concentrations of PCBs and had a much higher variation between individuals (de Yanés and Buthe, 1998).

Lower PCB concentrations than those measured in the North Sea were found in samples from the Gulf of St. Lawrence and Bay of Fundy/Gulf of Maine, NW Atlantic (Westgate et al., 1997). In 62 harbour porpoises from the Gulf of St. Lawrence, PCB blubber concentrations (sum of 68 congeners) in males and females were $10.6 \pm 5.4$ and $7.2 \pm 3.9 \mu \mathrm{g} / \mathrm{g}$ fresh weight, respectively. These concentrations were lower than those measured in 105 samples from the Bay of Fundy/Gulf of Maine, where PCB concentrations in blubber were $17.3 \pm 11.2$ and $11.4 \pm 4.8 \mu \mathrm{g} / \mathrm{g}$ fresh weight in males and females, respectively. These values have shown a decrease in concentration of organochlorine contaminants in porpoises during the last two decades in the NW Atlantic. Similar trends have been observed in the Baltic or Arctic populations (Bruhn et al., 1999).

However, some individuals from this study showed extremely high PCB values (up to $198.8 \mu \mathrm{g} / \mathrm{g}$ lipid for the sum of seven ICES markers) which might be due to local pollution or discharges. Re-suspension and run-off from old deposits of PCBs and DDTs are possibly higher in locations closer to industrialised regions. It has been shown (Kleivane et al., 1995) that for harbour porpoises, there is no large-scale migration between differ- ent locations and that these mammals are a good indicator of local pollution. Another possible explanation might be a particularly bad health condition of the animal; unfortunately, no information on the health status at the time of catching is available. It was shown (Jepson et al., 1999) that, due to infectious diseases, animals can loose weight rapidly. This will lead to a thinning of the blubber layer (in parallel with a redistribution of contaminants from the blubber) and thus to an increased concentration of organic pollutants in the blubber. However, these values are at the lower end of the concentrations (up to $3000 \mu \mathrm{g} / \mathrm{g}$ lipid) observed in marine mammals stranded during the 1988 and 1990 epizootic episodes (Aguilar and Borrell, 1994). Seasonal changes, availability of food and ambient water temperature at different locations are also factors that may affect the blubber thickness.

It has been suggested that the tissue distribution of pollutants might be slightly different when considering tissues with different lipid types and contents (Karlson et al., 2000). For three porpoises caught in the Baltic Sea, PCB concentrations (expressed per lipid weight) in the liver were slightly higher (1.25 times) than the concentrations in blubber, but almost double the concentrations found in muscle. Moreover, Zegers et al. (2001) have shown that for PBDEs, the concentration of pollutants in the liver of porpoises is 1.2 times higher than in the blubber. Brain was found to contain the lower concentrations (per lipid weight) due to the presence of phospholipids as major lipids (Karlson et al., 2000).

Percentage distribution of PCB homologues was consistent between samples (SD $<3 \%$ for the mean of percentages). Similar profiles of CBs were found by Karlson et al. (2000). The importance of single congeners was as follows: $153>138>149>187>180>$ $99>170$. These congeners are difficult to metabolise and are accumulated in females and males as well as in juvenile and adult porpoises. Distribution of some specific groups of PCBs (according to Boon et al., 1994) in porpoises was different in juveniles than in adults. Values of the ratio between the concentration of individual PCB congeners and CB 153 in porpoise liver were calculated for different groups (jm-juvenile/male, am-adult/ male, jf-juvenile/female and af-adult/female). The congeners have been divided into five structural groups with respect to the presence of vicinal $\mathrm{H}$ atoms and the number of ortho-Cl substituents (Boon et al., 1994). CB congeners 101, 110, 105, 118 (from groups III and IV) were found to have a higher contribution in juvenile individuals to the sum of total PCBs than the adults (Fig. 3). This might be due to an increased capacity of metabolism with the PCB body burden increase and thus with the age (Boon et al., 1997). All congeners in the groups I, II and V have been found to have similar ratios for all investigated groups of animals. 

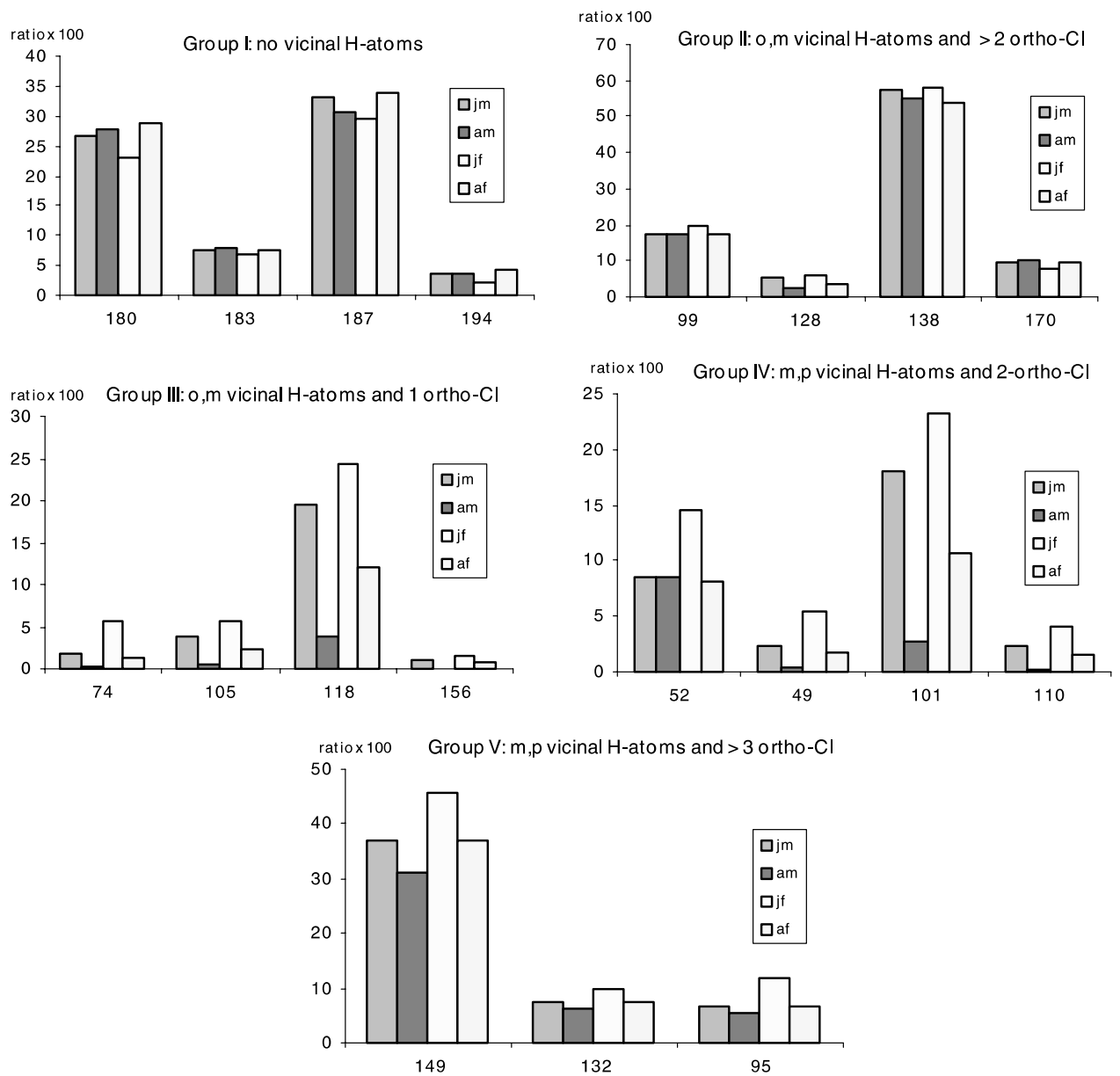

Fig. 3. Values of ratio between the concentration of individual CB congeners and CB 153 in porpoise liver for different groups. The congeners have been divided into five structural groups with respect to the presence of vicinal $\mathrm{H}$ atoms and the number of ortho-Cl substituents (Boon et al., 1994).

Most cetacean species have low hepatic cytochrome CYP450 2B activity, causing them to have little or no capacity for the metabolism of pure [phenobarbital]type PCBs (those with no vicinal meta-para hydrogen atoms) in contrast to seals and terrestrial mammals, which have a higher capacity to metabolise [PB]-type PCBs (Boon et al., 1994). It has been shown (Troisi et al., 1998) that, compared with whales or dolphins, harbour porpoises have a higher capacity for PCB methyl sulphone formation. Porpoises are able to metabolize nonortho CBs (77, 126 and 169) and some mono-ortho-CBs $(114,123,156)$, thus the TEQ toxicity is mainly derived from CBs 105 and 118 and to a lesser extent from PCB 167 and 189. It was found (Tanabe et al., 1997) that trito penta-PCB concentrations are lower in porpoises than in its prey (fish); thus, porpoises have the capacity to degrade lower chlorinated congeners. However, the ability of marine mammals to metabolise PCBs appears to be much lower compared to birds and terrestrial mammals (Tanabe et al., 1994) and even more in harbour porpoises than in many other cetaceans (Duinker et al., 1989). Therefore, the risk posed to harbour por- poises from chronic exposure to PCBs may be greater than in other species.

Very limited data are available on the contamination of harbour porpoises with PBDEs. Zegers et al. (2001) have shown a mean concentration of $0.9 \mu \mathrm{g} / \mathrm{g}$ lipid (range: $0.2-1.3 \mu \mathrm{g} / \mathrm{g}$ lipid) in 3 harbour porpoises caught on the Dutch coast of the North Sea. Higher levels (mean: 2.4 , range: $0.1-7.7 \mu \mathrm{g} / \mathrm{g}$ lipid) were measured in 60 harbour porpoises stranded on the English coast of North Sea and on the Welsh coast (Law et al., 2002). BDE 47 was the principal congener measured in all populations. These values are comparable with values measured in harbour porpoises from the Belgian coast (Table 2). It was suggested (Zegers et al., 2001) that, at least for invertebrates, concentrations of PBDEs are higher on the English coast when compared with the Dutch coast of the North Sea. This geographical distribution is in sharp contrast with PCB distribution.

Different lipid solubilities may to some extent explain the differences between organohalogenated compounds with regard to accumulation, distribution and elimination (Aguilar, 1985). The absence of accumulation of 
$\mathrm{HCH}$ isomers and $\mathrm{HCB}$ with age may indicate that these compounds are easier metabolised and/or more water soluble, so that a distribution equilibrium has been reached. Gaskin et al. (1983) revealed sex-related differences associated with organochlorine accumulation in porpoises, with no correlation between organochlorine blubber levels with age in mature females. This indicates an important organochlorine transfer from mother to offspring during the 6-8 month lactation period. Due to possible variation in organochlorine concentrations during development and maturation (Gaskin et al., 1983), it was essential to separate younger animals in the present study. Levels of other organohalogenated compounds (PCBs, DDTs and PBDEs) were significantly higher in the older age groups, thus revealing an age-dependent accumulation. Differences in food preferences with age may also play a role. These results are comparable with corresponding findings of Kleivane et al. (1995) on harbour porpoises, and indicate a relatively low metabolic capacity of small cetaceans with regard to these latter compounds. However, this cannot be solely attributed to a relatively low metabolic capacity, since it has been demonstrated by Boon et al. (1994) that harbour porpoises exhibit phenobarbital-type (PB-type) P450-enzyme activity. Specific bioaccumulation of DDTs, $\mathrm{HCHs}$ and $\mathrm{HCB}$, and variation in $\mathrm{PCB}$ composition between juvenile and mature harbour porpoises indicate different kinetics of these compounds. The difference found in PCB pattern between juvenile and mature porpoises may indicate the presence of a blood/placenta barrier and/or a selective mammary transport of PCBs with specific structures (Boon et al., 1997).

From eight male samples from the Black Sea (Tanabe et al., 1997), TEQ values of non- and mono-ortho CBs were recalculated using the toxicity equivalency factor (TEF) proposed by WHO (Van den Berg et al., 1998). TEQ values for non- and mono-ortho PCBs (NO- and MO-PCBs) were 56.6 and $113 \mathrm{pg} / \mathrm{g}$ lipid, with CBs 126 and 118 being the major contributors. The total TEQ value was $169.6 \mathrm{pg} / \mathrm{g}$ lipid which is similar with the value for MO-PCB TEQ found in males porpoises from this study. CBs 118 and 126 accounted for approximately $80 \%$ of the PCB-TEQ. In four porpoises from the Baltic Sea (Falandysz et al., 1998), NO- and MO-PCB TEQ were 9.8 and $74.3 \mathrm{pg} / \mathrm{g}$ lipid, respectively. CBs 126 and 118 constituted approximately $62 \%$ of PCB TEQ toxicity. It was shown (van Scheppingen et al., 1996) that contribution of PCDD/PCDFs is very low compared to the contribution of MO-PCBs (especially CB 105 and 118) and NO-PCBs (CB 126). It seems that harbour porpoises have a high metabolic capacity for $\mathrm{PCDD} /$ PCDFs, NO- and some MO-PCB congeners (CBs 114, 123 and 156) (van Scheppingen et al., 1996; Tanabe et al., 1997). In harbour porpoises from the North Sea, TEQ values for PCDD/PCDFs were between 1.1 and $3.6 \mathrm{pg} / \mathrm{g}$ lipid (Bruhn et al., 1999) or from 1.1 to
$1.8 \mathrm{pg} / \mathrm{g}$ lipid (van Scheppingen et al., 1996). However, comparison between data presented in the literature is rather difficult due to different TEF values used for TEQ calculations. It was recently shown (Jimenez et al., 2001) that for other marine mammals (such as pilot whale and some dolphin species), the contribution of mono-ortho PCBs to the total TEQs was between $60 \%$ and $99 \%$, while the contribution of PCDD/PCDFs was almost negligible. It was also shown (Ishaq et al., 2000) that polychlorinated naphthalenes (PCNs) make an insignificant contribution to total TEQ toxicity, lower than the TEQ toxicity from NOPCBs.

While concentrations of organochlorine pesticides (HCB, DDTs and $\mathrm{HCHs}$ ) in harbour porpoises stranded on the Belgian North Sea coast were low, relatively high concentrations of PCBs were measured. This indicates that there are still significant sources of PCBs in the marine environment. Furthermore, additional compounds must be included in monitoring campaigns (such as PBDEs) as, due to their massive use, concentrations in aquatic biota increased several fold in the last decades. As suggested already in the literature, juvenile animals are at risk due to high transfer of contaminants from mother and to differences between PCB congener profiles seen in juvenile and adults animals. PCBs have a much higher contribution to TEQ toxicity than PCDD/ PCDFs, as the harbour porpoises seem to have a decreased capacity of metabolising PCB congeners.

\section{Acknowledgements}

The authors wish to thank Robin Law (CEFAS, UK) for his valuable comments on the manuscript and for generously providing data for porpoises stranded on the English and Welsh coast. Thierry Ja niaux (University of Liége, Belgium) is acknowledged for all necropsies and biological data.

\section{References}

Aguilar, A., 1985. Compartmentation and reliability of sampling procedures in organochlorine pollution surveys of cetaceans. Residue Review 95, 91-114.

Aguilar, A., Borrell, A., 1994. Abnormally high PCB levels in striped dolphins (Stenella coeruleoalba) affected by the 1990-1992 Mediterranean epizootic. Science of the Total Environment 154, 237 247.

Berggren, P., Ishaq, R., Zebuhr, Y., Naf, C., Bandh, C., Broman, D., 1999. Patterns and levels of organochlorines (DDTs, PCBs, nonortho PCBs and $\mathrm{PCDD} / \mathrm{Fs}$ ) in male harbour porpoises (Phocoena phocoena) from the Baltic Sea, the Kattegat-Skagerrak Seas and the West coast of Norway. Marine Pollution Bulletin 38, 10701084 .

Boon, J.P., Oostingh, I., van der Meer, J., Hillebrand, T.J., 1994. A model for the bioaccumulation of chlorobiphenyl congeners in marine mammals. European Journal of Pharmacology 270, 237-251. 
Boon, J.P., van der Meer, J., Allchin, C.R., Law, R.J., Klungsoyr, J., Leonards, P.E.G., Spliid, H., Storr-Hansen, E., Mckenzie, C., Wells, D.E., 1997. Concentration-dependent changes of PCB patterns in fish-eating mammals: structural evidence for induction of cytochrome P450. Archives of Environmental Contamination and Toxicology 33, 298-311.

Bruhn, R., Kannan, N., Petrick, G., Schulz-Bull, D.E., Duinker, J.C., 1999. Persistent chlorinated organic contaminants in harbour porpoises from the North Sea, the Baltic Sea and Arctic waters. Science of the Total Environment 237/238, 351-361.

Covaci, A., deBoer, J., Ryan, J.J., Voerspoels, S., Schepens, P. Determination of PBDEs and PCBs in human adipose tissue by large volume injection-narrow bore capillary gas chromatography/electron impact-low resolution mass spectrometry. Analytical Chemistry, in press.

Covaci, A., Ryan, J.J., Schepens, P., 2002. Patterns of PCBs and PCDD/PCDFs in contaminated chicken and pork following a Belgian food contamination. Chemosphere 47 (2), 207-217.

Darnerud, P.O., Eriksen, G.S., Johannesson, T., Larsen, P.B., Viluksela, M., 2001. Polybrominated diphenyl ethers: occurence, dietary exposure and toxicology. Environmental Health Perspectives 109 (Suppl. 1), 49-68.

de Boer, J., Wester, P., Klamer, J., Lewis, W.E., Boon, J.P., 1998. Do flame retardants threaten ocean life? Nature 394, 28-29.

De Guise, S., Martineau, D., Beland, P., Fournier, M., 1995. Possible mechanisms of action of environmental contaminants on St. Lawrence beluga whales (Delphinapterus leucas). Environmental Health Perspectives 103 (4), 73-77.

de Yanés, G.S., Buthe, A., 1998. Variation of the composition of PCB mixtures in blubber of the harbour seal (Phoca vitulina) with sex, age and location. Organohalogen Compounds 39, 385-388.

Duinker, J.C., Hillebrand, M.T.J., Zeinstra, T., Boon, J.P., 1989. Individual chlorinated biphenyls and pesticides in tissues of some cetacean species from the North Sea and the Atlantic Ocean; tissue distribution and biotransformation. Aquatic Mammals 15, $95-124$.

Falandysz, J., Dembowska, A., Strandberg, L., Strandberg, B., Bergqvist, P.A., Rappe, C., 1998. PCBs in a pelagic food chain in the Southern Baltic Proper. Organohalogen Compounds 39, 53-57.

Gaskin, D.E., Frank, R., Holdrinet, M., 1983. Polychlorinated biphenyls in harbour porpoises (Phocoena phocoena) from the Bay of Fundy (Canada) and adjacent waters, with some information on chlordane and hexachlorobenzene levels. Archives of Environmental Contamination and Toxicology 12, 211-219.

Granby, K., Kinze, C.C., 1991. Organochlorines in Danish and West Greenland harbour porpoises. Marine Pollution Bulletin 22 (9), $458-462$.

Ishaq, R., Karlson, K., Naf, C., 2000. Tissue distribution of polychlorinated naphthalenes (PCNs) and non-ortho chlorinated biphenyls (non-ortho $\mathrm{CBs}$ ) in harbour porpoises (Phocoena phocoena) from Swedish waters. Chemosphere 41, 1913-1925.

Jacobs, M.N., Covaci, A., Schepens, P. PCBs in fish oil, feed and farmed-raised salmon from United Kingdom. Environmental Science and Technology, in press.

Jepson, P.D., Bennett, P.M., Allchin, C.R., Law, R.J., Kuiken, T., Baker, J.R., Rogan, E., Kirkwood, E., 1999. Investigating potential associations between chronic exposure to polychlorinated biphenyls and infectious disease mortality in harbour porpoises from England and Wales. Science of the Total Environment 243/244, 339-348.

Jimenez, B., Gonzalez, M.J., Rivera, J., 2001. POPs in top predators from the Mediterranean Sea. Organohalogen Compounds 51, 204 207.
Karlson, K., Ishaq, R., Becker, G., Berggren, P., Broman, D., Colmsjo, A., 2000. PCBs, DDTs and methyl sulphone metabolites in various tissues of harbour porpoises from Swedish waters. Environmental Pollution 110, 29-46.

Kleivane, L., Skaare, J.U., Bjorge, A., de Ruiter, E., Reijnders, P.J.H., 1995. Organochlorine pesticide residue and $\mathrm{PCBs}$ in harbour porpoise (Phocoena phocoena) incidentally caught in scandinavian waters. Environmental Pollution 89, 137-146.

Law, R.J., Allchin, C.R., 2001. Brominated flame retardants in the UK environment. In: Proceedings of the 2nd International Workshop on Brominated Flame Retardants Stockholm, Sweden, pp.139141.

Law, R.J., Allchin, C.R., Bennett, M.E., Morris, S., Rogan, E., 2002. Polybrominated diphenyl ethers in two species of marine top predators from England and Wales. Chemosphere 46, 673681

Ries, E.H., Traut, I.M., Brinkman, A.G., Reijnders, P.J.H., 1999. Net dispersal of harbour seals within the Wadden Sea before and after the 1988 epizootic. Journal of Sea Research 41, 233-244.

Smeenk, C., 1987. The harbour porpoise (Phocoena phocoena) in the Netherlands: stranding records and decline. Lutra 30, 77-90.

Tanabe, S., Iwata, H., Tatsukawa, R., 1994. Global contamination by persistent organochlorines and their ecotoxicological impact on marine mammals. Science of the Total Environment 154, 163177.

Tanabe, S., Madhusree, B., Ozturk, A.A., Tatsukawa, R., Miyazaki, N., Ozdamar, E., Aral, O., Samsun, O., Ozturk, B., 1997. Isomerspecific analysis of polychlorinated biphenyls in harbour porpoises (Phocoena phocoena) from the Black Sea. Marine Pollution Bulletin 34, 712-720.

Tanabe, S., Watanabe, S., Kan, H., Tatsukawa, R., 1988. Capacity and mode of PCB metabolism in small cetaceans. Marine Mammals Science 4 (2), 103-124.

Troisi, G.M., Haraguchi, K., Simmonds, M.P., Mason, C.F., 1998. Methyl sulphone metabolites of polychlorinated biphenyls (PCBs) in cetaceans from the Irish and the Aegean Seas. Archives of Environmental Contamination and Toxicology 35, 121-128.

Van den Berg, M., Birnbaum, L.S., Bosveld, A.T.C., Brunstrom, B., Cook, P., Feeley, M., Giesy, J.P., Hanberg, A., Hasegawa, R., Kennedy, S.W., Kubiak, T.J., Larsen, J.C., van Leeuwen, R.F.X., Liem, A.K.D., Nolt, C., Peterson, R.E., Poellinger, L., Safe, S., Schrenk, D., Tillitt, D., Tysklind, M., Younes, M., Waern, F., Zacharewski, T., 1998. Toxic equivalency factors (TEFs) for PCBs, PCDDs and PCDFs for humans and wildlife. Environmental Health Perspectives 106, 775-792.

van Scheppingen, W.B., Verhoeven, A.J.I.M., Mulder, P., Addink, M.J., Smeenk, C., 1996. Polychlorinated biphenyls, dibenzop-dioxins and dibenzofurans in harbour porpoises (Phocoena phocoena) stranded on the Dutch coast between 1990 and 1993. Archives of Environmental Contamination and Toxicology 30, 492-502.

Westgate, A.J., Muir, D.C.G., Gaskin, D.E., Kingsley, M.C.S., 1997. Concentrations and accumulation patterns of organochlorine contaminants in the blubber of harbour porpoises (Phocoena phocoena) from the coast of Newfoundland, the Gulf of St. Lawrence and the Bay of Fundy/Gulf of Maine. Environmental Pollution 95, 105-119.

Zegers, B.N., Lewis, W.E., Tjoen-A-Choy, M.R., Smeenk, C., Siebert, U., Boon, J.P., 2001. Levels of some polybrominated diphenyl ether flame retardants in animals of different trophic levels of the North Sea food web. In: Proceedings of the 2nd International Workshop on Brominated Flame Retardants Stockholm, Sweden, pp. $143-147$. 